\title{
Investigation of Properties of Fiber Reinforced Concrete Using Rubber Tyre Tube Wastage as Fibers
}

\author{
${ }^{1}$ Akshay Shirpurkar, ${ }^{* 2}$ Sumit S. Geete \\ ${ }^{1}$ Era Industries, Nagpur \\ ${ }^{2}$ Shri Ramdeobaba College of Engineering and Management, Nagpur, India \\ Email: ${ }^{1}$ shirpurkarav@rknec.edu, ${ }^{2}$ sumit.geete@gmail.com
}

Received: 06th November 2019, Accepted: 20th November 2019, Published: 31st December 2019

\begin{abstract}
Fiber reinforced concrete (FRC) is widely used as construction material. Fibers increase the structural integrity of concrete. Steel fibers, glass fibers, synthetic fibers and natural fibers are types of fibers used in FRC. Waste deposition of vehicles tyre after its useful life became critical issue to dispose off. In the present study preliminary investigation is carried out to check the feasibility of waste tyre tube material as fiber material in concrete. Waste tyre tube collected from different sources and cutting to aspect ratio 40 and called Rubber Tyre Tube Fiber (RTTF). Dose of RTTF is decided from the literature pertaining to FRC as $0.5 \%, 1.00 \%$ and $1.5 \%$ with respect to volume of concrete. Fresh and hardened properties of concrete are investigated with utilization of RTTF as fiber. Hardened state performance of RTTF reinforced concrete improved over the control mix. RTTF reinforced concrete is more crack resistance than control mix. Flow ability or workability of the concrete decrease with increment of dose of RTTF fiber because of formation of flocks. These flocks in the fresh concrete decrease the workability of concrete.
\end{abstract}

\section{Keywords}

Fiber Reinforced Concrete (FRC), Rubber Tyre Tube Fiber (RTTF), Slump

\section{Introduction}

Fiber reinforced concrete (FRC) is a composite material made with Portland cement, aggregate, admixture and incorporating discrete discontinuous Fibers. Plain, unreinforced concrete is a brittle material, with a low tensile strength and a low strain capacity. Randomly distributed fibers in concrete bridge the propagation of crack and minimize the increment in the width of crack. Fibers in the concrete are increases strain carrying capacity of concrete. The main purpose of adding any of Fiber types to concrete is not to prevent cracking but to control it. Steel and polypropylene fibers two mains types of fibers used in worldwide. The recommended dose of the fibers lies in the range of $20-40 \mathrm{~kg} / \mathrm{m}^{3}$ or $0.25-1.5 \%$ by volume of the concrete. As the dose of fiber in the concrete increases then flexural strength of concrete also increases [11]. Inclusion of fibers in the concrete reduced the workability of the concrete. Fibers impart heterogeneity to the FRC. Addition of polypropylene fibers to the concrete is responsible for the balling effect and reduction of the slump. The inclusion of the Fibers into the concrete mix influences its workability, with increasing in the Fiber volume and aspect ratio leading to decreased workability (Hannat, 1978; Swamy, 1974). Fibers are used super plasticizers to minimize the slump reduction of concrete. Fibers delay and control of tensile cracking of FRC [14].

Addition of the fibers slightly affects the compressive strength of the concrete ranging from $0-15 \%$. Tensile strength of concrete improved due to addition of fibers about 30-40\% [1]. Area under stress-strain curve is more in FRC as compared to non-FRC. Area under stress-strain curve represents toughness (Newman et al, 2003). Steel FRC is more durable than plain cement concrete and control the shrinkage cracks of the concrete [13].

Comparative experimental investigation reported between pain cement concrete and SFRC for slab on grade. Load carrying capacity of the slab on ground increase with the use of SFRC. Flexural toughness is the area under stressstrain graph. Flexural toughness of the SFRC is more than the plain cement concrete slab. It is proposed that friction between surface of slab of grade and the sub-grade is negligible effect on the load- carrying capacity [2]. Fiber improved the load- deflection property of the plain cement concrete. Tensile cracks in the FRC slab initiated at the same load irrespective of dose and type of fiber but well below the flexural cracking load. Slab flexural strength of slab is 1.8-2.2 times higher than flexural strength of beam. Flexural strength of the FRC is around 1.4 times flexural strength of the plain cement concrete. The flexural cracking load of the fiber reinforced slabs was $25-55 \%$ higher than the plain concrete slab. Optimum doses of the various types of fibers are proposed for slab on grade [16]. Failure pattern of slab on grade similar is to all types of slab failed under uniform load. As the dose of the steel fiber increase then ultimate load carrying capacity increases [15]. Effect of fiber content and diameter of steel fiber studied on the SFRC slab on grade. Modulus of elasticity tend to decrease with the increment with fiber content. 
Toughness of the concrete is mainly depends on the dose of the fibers [12]. Required thickness of the slab on grade depends on the magnitude of loading, modulus of sub-grade, reinforcement and grade of concrete [17].

In India, Rubber tube tyre waste is causing considerable damage to the environment. Rubber being a non-degradable material is difficult to dispose-off. The use of rubber will enhance quality of concrete it will surely reduce environmental pressure and hence an attempt has been made to understand whether they can be successfully used in concrete to improve some of the mechanical properties as in the case of the other fibers. Up till now the studies are being carried out on the various materials such as steel fibers, polypropylene fiber, synthetic fiber, glass fiber etc. In this study the bicycle tube tyre utilized in concrete as a substitute to other fibers which are available in the market.

\section{Methodology}

The primary objective of this investigation is to study experimentally the properties of fiber reinforced concrete containing rubber tube tyre fibers. The said material was inserted in the proportions of $0.5 \%, 1.00 \%$ and $1.5 \%$ in the concrete mixture with respect to the cementatious material. The properties of concrete, namely, Compressive strength, split tensile Strength and flexural strength were studied on the concrete produced by utilizing the fiber reinforcement concrete mixture. The rubber tyre tube was converted to fiber. Rubber tyre tube was collected from the waste yard of commercial area of Nagpur and were washed and shredded manually to the cross sectional dimension of $1.5 \mathrm{~mm}$ by $1.5 \mathrm{~mm}$ and length of $60 \mathrm{~mm}$ keeping the aspect ratio of 40 .

\begin{tabular}{|l|l|l|}
\hline $\begin{array}{l}\text { Portland Pozzolana Cement (Fly ash } \\
\text { Based) }\end{array}$ & Fine Aggregate (Natural Sand) & Coarse Aggregate \\
\hline Fineness $=5 \%$ & Fineness Modulus $=2.4$ & Fineness Modulus $=6.8$ \\
\hline Standard Consistency $=29 \%$ & Silt Content $=0.75 \%$ & Silt Content $=0.25 \%$ \\
\hline $\begin{array}{l}\text { Compressive Strength of PPC cubes } \\
7 \text { Days }=18 \mathrm{~N} / \mathrm{mm}^{2} \\
28 \text { Days }=48 \mathrm{~N} / \mathrm{mm}^{2}\end{array}$ & Water Absorption $=1.7 \%$ & Water Absorption $=0.8 \%$ \\
\hline Soundness of Cement $=4 \mathrm{~mm}$ & Specific Gravity $=2.67$ & \\
\hline
\end{tabular}

Table 1: Details of Material Properties [5,6,7]

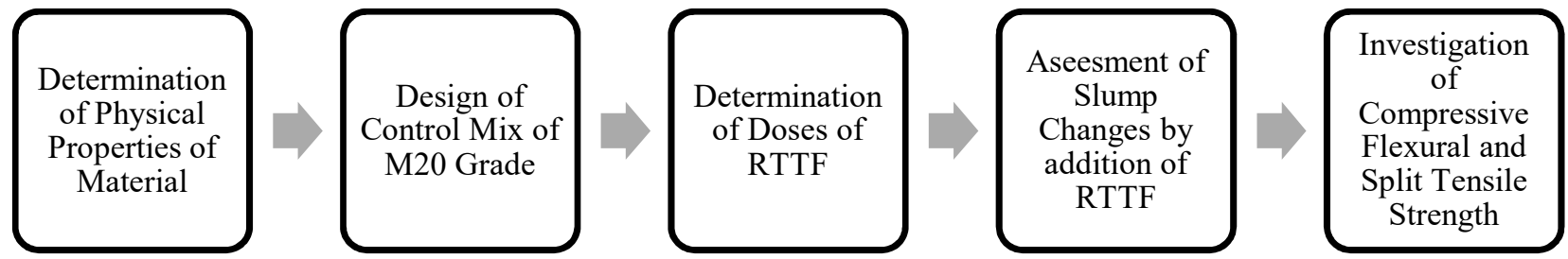

Figure 1: Methodology of Investigation of Properties of RTTF Concrete

Proportioning of M20 grade of concrete as a control mix assessed as per IS : 10262 - 2009. Slump requirement is $100 \mathrm{~mm}$. Admixture is not used for casting of M25 grade of control mix.

\begin{tabular}{|c|c|c|c|c|c|}
\hline Sr. No & Name of Test & Specimen & $\begin{array}{l}\text { No of } \\
\text { specimen }\end{array}$ & $\%$ of fiber added & Days of curing \\
\hline \multirow{2}{*}{1.} & \multirow{2}{*}{ Compression test } & \multirow{2}{*}{ Cube : $150 \times 150 \times 150 \mathrm{~mm}$} & 12 Nos & \multirow{2}{*}{$\mathrm{CM}, 0.5 \%, 1.00 \%, 1.50 \%$} & 07 days \\
\hline & & & 12 Nos & & 28 days \\
\hline \multirow{2}{*}{2.} & \multirow{2}{*}{ Split tensile test } & \multirow{2}{*}{ Cylinder : 100x200mm } & 12 Nos & \multirow{2}{*}{$\mathrm{CM}, 0.5 \%, 1.00 \%, 1.50 \%$} & 07 days \\
\hline & & & $12 \mathrm{Nos}$ & & 28 days \\
\hline \multirow{2}{*}{3.} & \multirow{2}{*}{ Flexural test } & \multirow{2}{*}{ Beam : 150x150x700mm } & 06 Nos & \multirow{2}{*}{$\mathrm{CM}, 0.5 \%, 1.00 \%, 1.50 \%$} & 07 days \\
\hline & & & 06 Nos & & 28 days \\
\hline
\end{tabular}

Table 2: Details of Specimens 
Results and Discussion

\begin{tabular}{|c|c|c|c|c|c|c|c|c|}
\hline \multirow[t]{2}{*}{ SN } & \multirow{2}{*}{$\begin{array}{l}\% \text { of } \\
\text { fiber }\end{array}$} & \multicolumn{2}{|c|}{$\begin{array}{l}\text { Compressive } \\
\text { strength (MPa) }\end{array}$} & \multicolumn{2}{|c|}{$\begin{array}{lll}\text { Split } & \text { Tensile } & \text { Strength } \\
(\mathrm{MPa}) & & \\
\end{array}$} & \multicolumn{2}{|c|}{$\begin{array}{l}\text { Flexural Strength } \\
\text { (MPa) }\end{array}$} & \multirow{2}{*}{$\begin{array}{l}\text { Slump } \\
\mathbf{m m}\end{array}$} \\
\hline & & 7 days & 28 days & 7 days & 28 days & 7 days & 28 days & \\
\hline 1 & $0 \%$ & 22.26 & 34.9 & 1.47 & 3.762 & 1.591 & 3.762 & 110 \\
\hline 2 & $0.50 \%$ & 25.12 & 38 & 1.62 & 4.235 & 1.687 & 4.514 & 98 \\
\hline 3 & $1.00 \%$ & 26.54 & 42.62 & 1.87 & 4.505 & 2.024 & 4.658 & 72 \\
\hline 4 & $1.50 \%$ & 28.65 & 44.17 & 2.41 & 4.65 & 2.451 & 4.827 & 60 \\
\hline
\end{tabular}

Table 3: Variation of Strength Properties of Concrete with Dose of Fiber [8,9,10]

\begin{tabular}{|c|c|c|c|c|c|c|c|c|c|}
\hline \multirow[t]{2}{*}{$\mathbf{S N}$} & \multirow[t]{2}{*}{$\begin{array}{l}\% \text { of } \\
\text { fiber }\end{array}$} & $\begin{array}{l}\text { Compressive } \\
\text { strength } \\
\text { (MPa) }\end{array}$ & $\begin{array}{l}\text { Flexural } \\
\text { Strength } \\
\text { (MPa) }\end{array}$ & $\begin{array}{l}\text { Split } \\
\text { Tensile } \\
\text { Strength } \\
\text { (MPa) } \\
\end{array}$ & Slump & \multirow[t]{2}{*}{$\begin{array}{l}\text { \% } \\
\text { Increment } \\
\text { in } \\
\text { Compressive } \\
\text { Strength }\end{array}$} & \multirow{2}{*}{$\begin{array}{l}\text { \% } \\
\text { Increment } \\
\text { in Split } \\
\text { Tensile } \\
\text { Strength }\end{array}$} & \multirow{2}{*}{$\begin{array}{l}\% \\
\text { Increment } \\
\text { in } \\
\text { Flexural } \\
\text { Strength }\end{array}$} & \multirow[t]{2}{*}{$\begin{array}{l}\% \\
\text { Decrement } \\
\text { in Slump }\end{array}$} \\
\hline & & 28 days & 28 days & 28 days & $\mathbf{m m}$ & & & & \\
\hline 1 & $0 \%$ & 34.9 & 3.762 & 3.762 & 110 & 0.00 & 0.00 & 0.00 & 0.00 \\
\hline 2 & $0.50 \%$ & 38 & 4.235 & 4.514 & 98 & 8.88 & 12.57 & 19.99 & -10.91 \\
\hline 3 & $1.00 \%$ & 42.62 & 4.505 & 4.658 & 72 & 22.12 & 19.75 & 23.82 & -34.55 \\
\hline 4 & $1.50 \%$ & 44.17 & 4.65 & 4.827 & 60 & 26.56 & 23.60 & 28.31 & -45.45 \\
\hline
\end{tabular}

Table 4: Variation of \% Strength of Concrete with Dose of Fiber

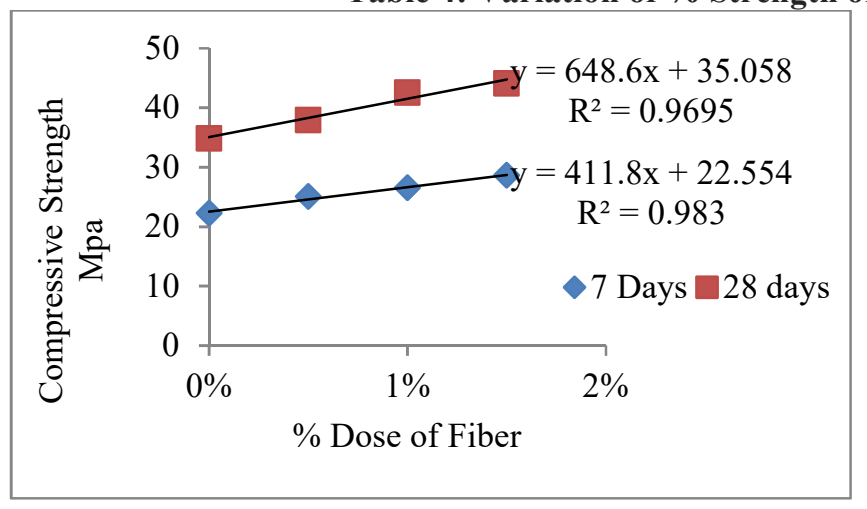

Graph 1 : Compressive Strength Variation With RTTF Dose

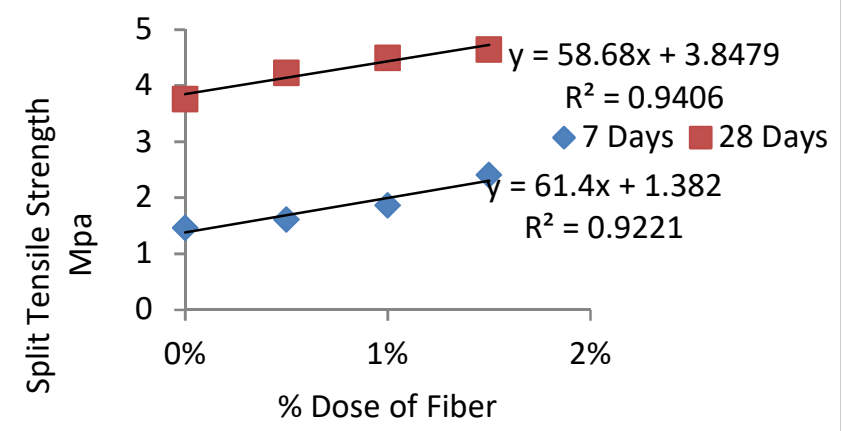

Graph 3 : Split Tensile Strength Variation With RTTF Dose

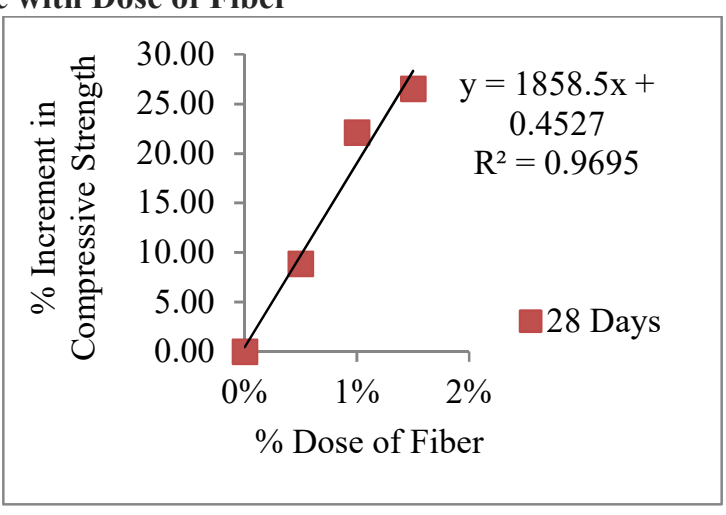

Graph 2 : Incremental Increase in Compressive Strength With RTTF Dose

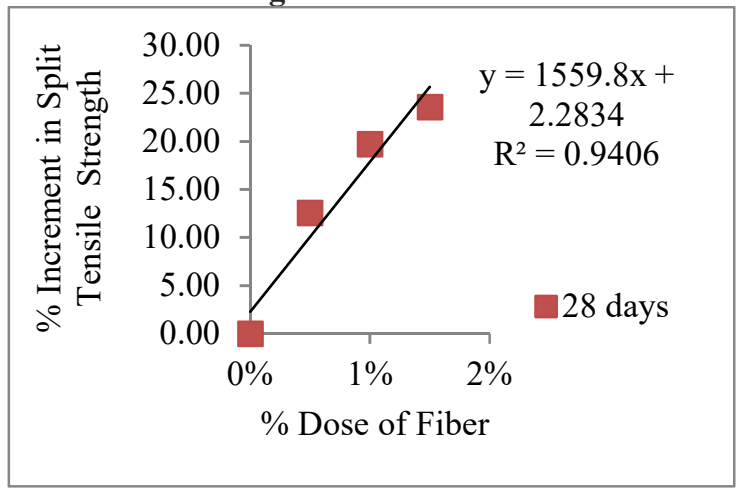

Graph 4 : Incremental Increase in Split Tensile Strength With RTTF Dose 


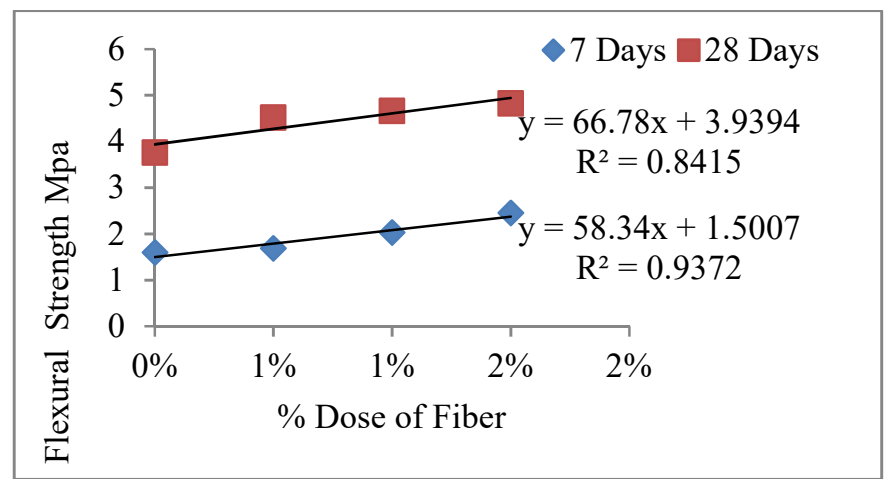

Graph 5 : Flexural Strength Variation With RTTF Dose

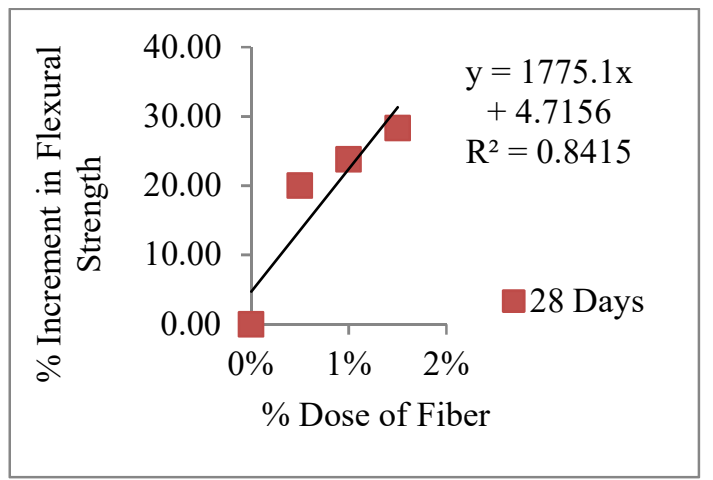

Graph 6 : Incremental Increase in Flexural Strength With RTTF Dose

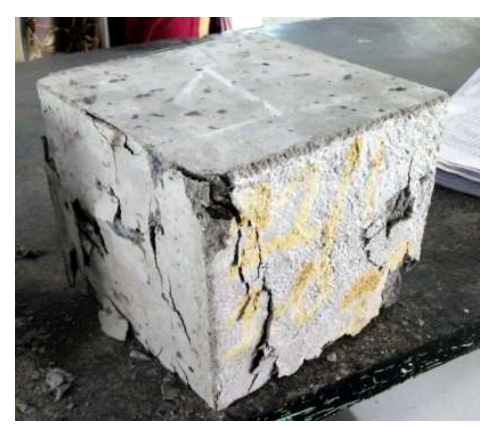

Figure 2: Compressive Failure

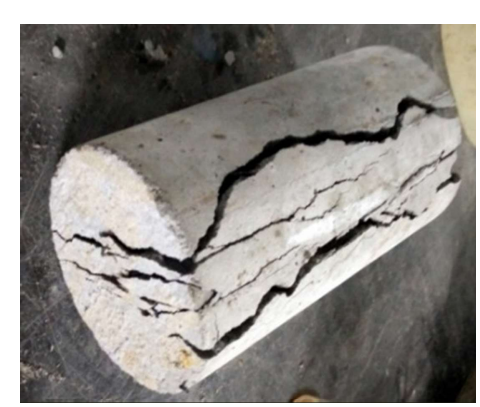

Figure 3: Tensile Failure

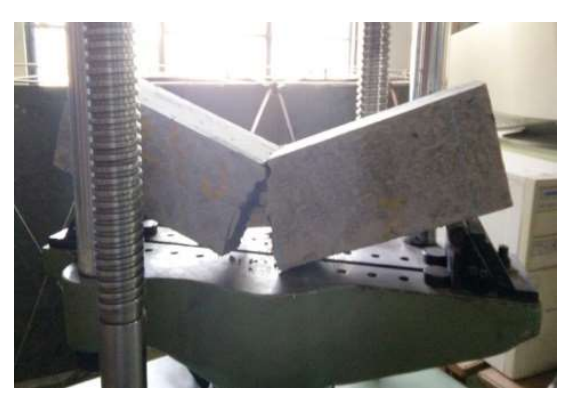

Figure 4: Flexural Failure

From based on experimental results following points are concluded:

1. With increment in the dose of the RTTF, the compressive, flexural and slit tensile strength increases considerable. This increment in the strength could be arresting the cracks propagation through the fibers distributed in the body of specimens.

2. From the experimental investigation, time for failure of for compression testing is increases with increment of the dose of RTTF. This is concluded than the post crack increment in deflection of the concrete. Post crack increment in the deflection of concrete responsible for the increment in the peak load of RTTF concrete failure.

3. Incremental increase in compression, split tensile and flexural strength of RTTF concrete increases with the increment of the dose of the concrete.

4. Retention of concrete or slump of concrete decreases with the increment of concrete. Addition of fiber causes balling effect i.e. formation of the flocks of fresh concrete and these flocks creates resistances to the flow ability of concrete.

\section{Conclusion}

Based on the preliminary experimental investigation, it is concluded that addition of RTTF improved the hardened properties of concrete i.e. compressive strength, split tensile strength and flexural strength. RTTF could be use as fiber in fiber reinforced concrete. Addition of RTTF to the concrete reduced the workability of concrete because of balling effect. To counterbalance this balling effect, it is necessary to use the plasticizers or super plasticizer. Again it is necessary to study stress-strain behaviour of the RTTF concrete with load deflection curve.

\section{References}

1. ACI Committee 544 (1996) Fiber reinforced concrete (ACI 544.1R). American Concrete Institute, Farmington Hills, Michigan

2. Chen, Shiming. 2004. "Strength of Steel Fibre Reinforced Concrete Ground Slabs." Proceedings of the Institution of Civil Engineers: Structures and Buildings 157(2): 157-63. 
3. Hannat, D., (1978) Fibre cements and fibre concretes, Jphn Wiley \& Sons, New York.

4. IS: 10086. 1981. Indian Standard "Specification for moulds for use in tests of cement and concrete" - Code of practice. Bureau of Indian Standards, New Delhi.

5. IS: 10262. 1982. Indian Standard "Recommended Guidelines for Concrete Mix Design"- Code of practice. Bureau of Indian Standards, New Delhi.

6. IS: 1489. 1991 (part 1). Indian standard "Portland pozzolana cement specification part 1 fly ash based" (Third revision) - Code of practice. Bureau of Indian Standards, New Delhi.

7. IS: 383. 1963. Indian Standard "Specification for Coarse and Fine Aggregates from Natural Sources for Concrete"- Code of practice. Bureau of Indian Standards, New Delhi.

8. IS: 456. 2000. Indian Standard "Plain and Reinforced Concrete" - Code of practice. Bureau of Indian Standards, New Delhi.

9. IS: 516. 1959. Indian Standard "Methods of Tests for Strength of Concrete"- Code of practice. Bureau of Indian Standards, New Delhi.

10. IS: 5816. 1999. Indian Standard "Splitting tensile strength of concrete method of test" (First revision) - Code of practice. Bureau of Indian Standards, New Delhi.

11. Labib, Wafa, and Nick Eden. 2006. "An Investigation into the Use of Fibres in Concrete Industrial Ground-Floor Slabs." 3rd International Built a. Human Environment Research Week: 466-77. http://www.irbnet.de/daten/iconda/CIB9056.pdf.

12. Neves, R. D., and J. C. O. Fernandes de Almeida. 2005. "Compressive Behaviour of Steel Fibre Reinforced Concrete." Structural Concrete 6(1): 1-8.

13. Newman, J. and Choo, B., (2003) Advanced concrete technology (processes), Elsevier Ltd, Oxford.

14. Ramakrishnan, V., (1988) Materials and properties of fibre reinforced concrete, Civil Engineering, April, pp. 2940, London.

15. Roberts-Wollmann, Carin L., Marcela Guirola, and W. Samuel Easterlina. 2004. "Strength and Performance of Fiber-Reinforced Concrete Composite Slabs." Journal of Structural Engineering 130(3): 520-28.

16. Roesler, Jeffery R. et al. 2004. "Fracture of Plain and Fiber-Reinforced Concrete Slabs under Monotonic Loading." Journal of Materials in Civil Engineering 16(5): 452-60.

17. Zlogas, Vigantas, and Svajunas Juocnas. 2005. "Design and Installation Peculiarities of Monolithic Concrete Floor." Journal of Civil Engineering and Management 11(2): 153-62. 